\title{
TRITERPENOIDS FROM Azorella trifurcata (Gaertn.) Pers AND THEIR EFFECT AGAINST THE ENZYME ACETYLCHOLINESTERASE
}

\author{
Carlos Areche, Patricia Cejas, Pablo Thomas y Aurelio San-Martín* \\ Department of Chemistry, Faculty of Sciences, University of Chile, Santiago, Chile \\ Luis Astudillo y Margarita Gutiérrez \\ Institute of Chemistry of Natural Resource, University of Talca, Talca, Chile \\ Luis A Loyola \\ Department of Chemistry, Faculty of Basic Sciences, University of Antofagasta, Antofagasta, Chile
}

Recebido em 15/7/08; aceito em 4/5/09; publicado na web 6/10/09

\begin{abstract}
The inhibition of the enzyme acetylcholinesterase is considered as a strategy for the treatment of Alzheimer's disease, senile dementia, ataxia, and myasthenia gravis. Three lanostane- and two cycloartane-type triterpenes, together with two mulinane-type diterpenes were isolated from petroleum ether extract of the whole shrub of Azorella trifurcata (Gaertn.) Pers. Their effect on the enzyme acetylcholinesterase was assessed as well. In addition, this is the first report of these triterpenes in the genus Azorella.
\end{abstract}

Keywords: Azorella; Umbelliferae; triterpenes.

\section{INTRODUCTION}

The principal role of acetylcholinesterase (AChE) is to decrease the amount of acetylcholine (ACh) in the cholinergic neurons and to terminate the nerve impulse transmission. Inhibition of $\mathrm{AChE}$ serves as a strategy for the treatment of Alzheimer's disease (AD), senile dementia, ataxia, myasthenia gravis and Parkinson's disease and it has been considered as one potential therapeutic approach to Alzheimer's disease. Many research groups are making considerable efforts to find quality AChE inhibitors derived from natural sources because several synthetic medicines, e.g. tacrine, donepezil and the natural product-based rivastigmine have been reported to have adverse effects. These medicines are also available for the symptomatic treatment of patients with mild to moderate AD. ${ }^{1,2}$ Some naturally occurring acetylcholinesterase inhibitors have been isolated from plants. ${ }^{2}$ Additionally, it has recently been revealed that some cycloartane-type triterpenes were found to exhibit weak AChE inhibitory activity. ${ }^{3}$ Many triterpenoids have a unique range of potentially viable biological effects, such as anti-inflammatory, antiulcerogenic, analgesic, antimicrobial, antimycotic, antiplasmodial, hepatoprotective, virostatic, immunomodulatory and tonic. ${ }^{4}$

The most typical species of Azorella genus is A. compacta, which is native shrub that grows in the high Andes, in northeastern Chile. The whole plant is used in indigenous medicine to treat a large variety of ailments, such as bronchitis, asthma and colds and its metabolites have important biological activities..$^{5-7}$ Another species belonging to this genus is A. trifurcata which grows in humid prairies. Previous phytochemical studies of $A$. trifurcata reported the isolation of polyacetylenic compounds. ${ }^{8}$

In this study, we report the isolation and identification of the triterpenoids contained in Azorella trifurcata (Gaertn.) Pers and their activity on the acetylcholinesterase enzyme.

\section{EXPERIMENTAL}

\section{Procedure}

Optical rotations were obtained in $\mathrm{CHCl}_{3}$ on a Perkin-Elmer

*e-mail: aurelio@uchile.cl
Model 241 polarimeter. The compounds were dissolved in $1.0 \mathrm{~mL}$ of chloroform- $d\left(\mathrm{CDCl}_{3}\right)$ containing tetramethylsilane (TMS) as internal standard. Chemical shifts $(\delta)$ were reported in ppm and coupling constants $(J)$ in Hertz. ${ }^{1} \mathrm{H}-\mathrm{NMR}$ spectra were measured at 400.13 $\mathrm{MHz}$ and ${ }^{13} \mathrm{C}$-NMR data were obtained at $100.61 \mathrm{MHz}$ on a Bruker instrument. Spectral assignments were made with the assistance of DEPT and HMBC when it was necessary. Mass spectra were recorded on a V.G. Micromass, ZAB-2R spectrometer.

TLC spots were visualized by spraying the chromatograms with $\mathrm{H}_{2} \mathrm{SO}_{4}$-methanol (1:9) and heating at $110^{\circ} \mathrm{C}$ for $2 \mathrm{~min}$. Column chromatography was performed over Merck Kieselgel 60, particle size 0.063-0.200 mm, impregnated with $\mathrm{AgNO}_{3}$. All solvents were dried and purified before use according to standard procedures.

\section{Plant material}

The whole shrub of Azorella trifurcata (Gaertn.) Pers (Umbelliferae) was collected in Lago Panguipulli coast, Chile in January 2006. Voucher samples ( $N^{\circ}$ 2006/05) are deposited in the Herbarium of University of Concepción. The plant was then dried at room temperature and finely powdered. The plant was identified by Prof. Clodomiro Marticorena, University of Concepción, Concepción, Chile and a voucher specimen was deposited at the Herbarium of the University of Concepción.

\section{Extraction and isolation of triterpenos}

The powdered whole plant of Azorella trifurcata $(1 \mathrm{~kg})$ was extracted with petroleum ether (PE) $(2 \times 3 \mathrm{~L}$ each) at room temperature. The solvent was filtered and evaporated under reduced pressure affording $30 \mathrm{~g}$ of yielding gum. The extract was chromatographed in a silica gel open column ( $200 \mathrm{~g})$ using a PE-EtOAc gradient system (0 to $100 \%$; 1 L each) affording five fractions: EP 100\% (fr-1; $1.5 \mathrm{~g}$ ), EP-EtOAc 20\% (fr-2; 3 g), EP-EtOAc 40\% (fr-3; 7 g), EP-EtOAc 60\% (fr-4; $3.5 \mathrm{~g}$ ) and EtOAc $100 \%$ (fr-5; $1.0 \mathrm{~g}$ ). The fr-1 was chromatographed on silica gel affording waxes and fatty acids. The fr- 2 was further purified by column chromatography on silica gel impregnated with $\mathrm{AgNO}_{3}(10 \%)$ with a petroleum ether-dichloromethane (DCM) gradient (0 to 100\%) gave the following triterpenes: 1 (lanost-7-en-3 $\beta$-ol; $10 \mathrm{mg}$ ); 2 (lanost-9(11)-en- 


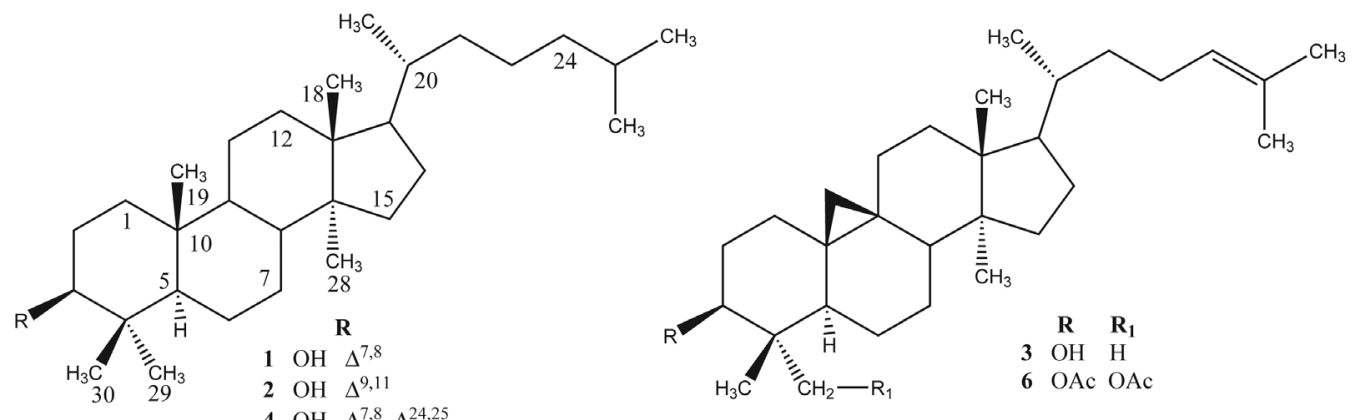

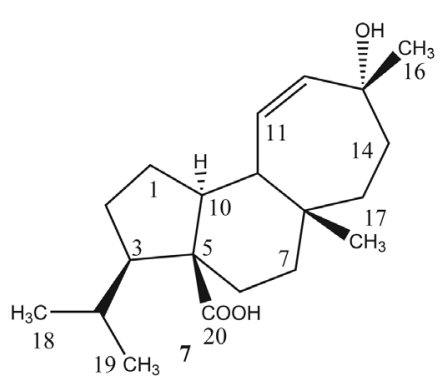

Figure 1. Structure of the compounds isolated from Azorella trifurcata

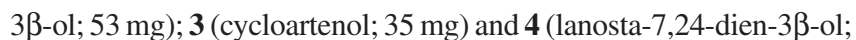
$69 \mathrm{mg}$ ). The fr- 3 was acetylated by the standard manner. ${ }^{9}$ Then, it was chromatographed again by column chromatography on silica gel impregnated with $\mathrm{AgNO}_{3}$ using a PE-EtOAc gradient (0 up to 20\%)

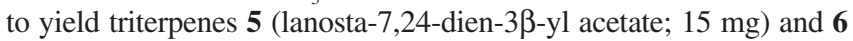
(28-acetoxycycloartenyl acetate; $5 \mathrm{mg}$ ). After several chromatographic separations, the fr- 4 yielded the known diterpenes 7 (mulinolic acid; $100 \mathrm{mg}$ ) and 8 (mulin-11,13-dien-20-oic acid; $300 \mathrm{mg}$ ).

\section{Acetylcholinesterase inhibition assay}

Inhibitory activity against AChE was evaluated at room temperature by the colorimetric method previously described. ${ }^{10}$ The final concentration containing test compound of the assay solution consisted of sodium phosphate buffer ( $\mathrm{pH} 7.6$ ) and $0.25 \mathrm{U} / \mathrm{mL}$ of $\mathrm{AChE}$ from Electroporus electricus. The assay solutions except substrate were preincubated with the enzyme for $30 \mathrm{~min}$ at room temperature. After preincubation, the substrate was added. The solution substrate consists of $\mathrm{Na}_{2} \mathrm{HPO}_{4}(40 \mathrm{mM})$, acetylthiocholine $(0,24 \mathrm{mM})$ and 5,5'-dithio-bis(2-nitrobenzoic acid) (0.2 mM, DTNB, Ellman's reagent). Hydrolysis of acetylthiocholine by acetylcholinesterase produces thiocholine. The non-enzymatic reaction of thiocholine with 5,5'-dithio-bis-(2nitrobenzoic acid) produces 5-thio-2-nitrobenzoic acid, which has a yellow colour and strong absorbance at $405 \mathrm{~nm}$. The absorbance changes at $405 \mathrm{~nm}$ were recorded for 3 min with a microplate reader Multiskan EX (Thermo, Finland). The AChE inhibition was determined for each compound. The enzyme activity was calculated as a percentage compared to a control using only the buffer and enzyme solution. The compounds were assayed in the dilution interval of $250-15 \mu \mathrm{g} / \mathrm{mL}$, and the alkaloid galanthamine was used as the reference compound. Each assay was run in triplicate and each reaction was repeated at least three independent times. The $\mathrm{IC}_{50}$ values were calculated by means of regression analysis.

\section{RESULTS AND DISCUSSION}

From petroleum ether extract of the whole shrub of Azorella trifurcata over silica gel, impregnated with $\mathrm{AgNO}_{3}$, five triterpenoids were isolated from which compounds $\mathbf{5}$ and $\mathbf{6}$ were isolated as acetates along with two known mulinane-type diterpenoids 7-8. The chemical structures of the compounds are shown in Figure 1. The identification of compounds 1-6 were done on the basis of their spectroscopic analysis and physical properties (mainly $[\alpha]_{\mathrm{D}}^{20}$ ) and compared with literature data. Finally the structures of diterpenes $\mathbf{7}$ and $\mathbf{8}$ were established by comparison of spectroscopic data with standard samples obtained in previous chemical studies of several species of Apiaceae..$^{11,12}$

The ${ }^{1} \mathrm{H}-\mathrm{NMR}$ spectrum of $\mathbf{1}$ showed signals of eight methyl groups: $\delta 0.80,0.87,0.92(6 \mathrm{H}), 1.01,1.04,1.17$ and $1.29 \mathrm{ppm}$. The signal at $\delta 5.22(1 \mathrm{H}$, brt, $J=3.4)$ was due to an olefinic proton while the proton geminal to the hydroxyl group was observed at $\delta 3.25(1 \mathrm{H}$, $\mathrm{dd}, J=11.5,4.2)$. These signals were characteristic of a $\Delta^{7}$ lanostane skeleton with a hydroxyl group in ring $\mathrm{A} .{ }^{13}$

The compound 2 was established as follows: The ${ }^{1} \mathrm{H}-\mathrm{NMR}$ spectrum exhibited signals for eight methyl groups at $\delta 0.77,0.81,0.85$ $(6 \mathrm{H}), 0.92,0.95,0.98$ and $1.12 \mathrm{ppm}$, along with a triplet at $\delta 5.16$ $(1 \mathrm{H}, \mathrm{t}, J=4.0)$ for an olefinic proton and a proton geminal at $\delta 3.20$ $(1 \mathrm{H}, \mathrm{dd}, J=10.9,3.9)$ joined to a hydroxyl group. These data showed agreement to a $\Delta^{9}$ lanostane skeleton with a hydroxyl group in ring $\mathrm{A} .{ }^{13}$

The compound 3 showed a cyclopropyl methylene ( $\delta 0.31$ and $0.53 \mathrm{~d}, J=4.0 \mathrm{~Hz})$ in the ${ }^{1} \mathrm{H}-\mathrm{NMR}$ spectrum, along with seven methyl groups at $\delta 0.79,0.86,0.87(6 \mathrm{H}), 0.95,1.58$ and 1.66 , a proton at $\delta$ $3.26(1 \mathrm{H}, \mathrm{m})$ and a proton signal at $\delta 5.10(1 \mathrm{H}, \mathrm{t}, J=7.0 \mathrm{~Hz})$, suggesting a cycloartane type of triterpenoid. These data are consistent with the compound 3 . $^{14}$

The ${ }^{1} \mathrm{H}-\mathrm{NMR}$ spectrum 4 showed signals for eight methyl groups: $\delta 0.72,0.79,0.84(6 \mathrm{H}), 0.95(6 \mathrm{H}), 1.58$ and $1.66 \mathrm{ppm}$. The signals at $\delta 5.23(1 \mathrm{H}$, brd, $J=6.0)$ and $\delta 5.08(1 \mathrm{H}$, brt, $J=6.7)$ were due to two olefinic protons while the signal at $3.22(1 \mathrm{H}, \mathrm{dd}, J=10.7,4.9)$ is attached to a hydroxyl group at $\mathrm{C}-3$. These signals are characteristic of a $\Delta^{7,24}$ lanostane skeleton with a hydroxyl group in ring $\mathrm{A} .{ }^{13}$ The compound $\mathbf{5}$ was an acetate from $\mathbf{4}$.

The compound $\mathbf{6}$ was deduced as follows: The molecular formula was proved to be $\mathrm{C}_{30} \mathrm{H}_{54} \mathrm{O}_{4}$ based on HREIMS and ${ }^{13} \mathrm{C}$-NMR data. The ${ }^{1} \mathrm{H}-\mathrm{NMR}$ spectrum showed signals at $\delta 0.43(\mathrm{~d}, J=4.3)$ and $0.62(\mathrm{~d}, J=4.3)$ for a cyclopropyl methylene, along with two methyl groups $(\delta 2.0$ and 2.1$)$ and four methyls at $\delta 0.92(6 \mathrm{H})$, 
0.95 and 1.01 . The presence of only two vinyl methyls at $\delta 1.65$ and 1.73 , a vinyl proton at $\delta 5.14(1 \mathrm{H}, \mathrm{t}, J=7.1)$ and the protons geminal to the acetoxy groups $[\delta 4.93 \mathrm{~m}, 3.80 \mathrm{~d}$ and $3.95(\mathrm{~d}, J=$ 11.4)] indicated a cycloartane triterpenoid. HMBC correlations showed that the $-\mathrm{CH}_{2} \mathrm{OAc}$ was attached to $\mathrm{C}-4$ and a high field chemical shift of C-29 at $\delta 11.4$, suggesting that compound $\mathbf{6}$ is 28-hydroxycycloartenol, isolated like an acetate. ${ }^{15}$

The metabolites obtained were evaluated toward the enzyme $\mathrm{AChE}$, and whose results of this inhibition are shown in Table 1. All compounds showed moderate inhibitory activity toward the enzyme $\mathrm{AChE}$, and the most active were the compounds $\mathbf{5}$ and $\mathbf{6}$ with $\mathrm{IC}_{50}$ values of 0.46 and $0.42 \mathrm{mM}$, respectively. The higher level of activity among these compounds may be due to the presence of acetate groups. It is also possible to note that changes in the position of the insaturations within the same chemical skeleton generate changes in the evaluated activity as observed for compounds $\mathbf{1}$ and $\mathbf{2}$.

Table 1. Activity of compounds 1-8 toward the enzyme acetylcholinesterase

\begin{tabular}{ccc}
\hline Compound & $\mathrm{IC}_{50}(\mu \mathrm{g} / \mathrm{mL})$ & $\mathrm{IC}_{50}(\mu \mathrm{M})$ \\
\hline $\mathbf{1}$ & 340 & 790 \\
$\mathbf{2}$ & 240 & 560 \\
$\mathbf{3}$ & 240 & 550 \\
$\mathbf{5}$ & 350 & 810 \\
$\mathbf{6}$ & 210 & 460 \\
$\mathbf{7}$ & 220 & 420 \\
$\mathbf{8}$ & 200 & 630 \\
Galanthamine & 180 & 580 \\
\hline
\end{tabular}

The compounds 1-6 were previously reported from Psolus fabricii, Holothuria scabra and Garcinia lucida. ${ }^{16}$ Compound 3 is a precursor of cholesterol and other sterols in all green plants with hypocholesterolemic activity by the inhibition of cholesterolesterase. ${ }^{16-18}$ The compounds $\mathbf{5}$ and $\mathbf{6}$ were previously isolated from natural sources. ${ }^{16}$ Our study provides evidence, for the first time, of the presence of triterpenes 1-4 and $\mathbf{6}$ in the genus Azorella.

Up to now, there are few natural products isolated from higher plants that show activity toward AChE enzyme, e.g. galanthamine, huperzine A, and they are routinely used as medicines for the treatment of different forms of dementia. ${ }^{2}$ Several triterpenoids from natural sources have been shown to inhibit AChE enzyme, which is an essential enzyme in the termination of the nerve impulse transmission. Among them, artocarpuate $\mathrm{A}$, artocarpuate $\mathrm{B}$ and $\alpha$-onocerin have also been cited. ${ }^{3,19}$ Some biological activities have been reported for lanostane-type triterpenes, but none have been found to be related to an activity toward the enzyme AChE. ${ }^{20,21}$ Further semi-synthetic derivatives are necessary to disclose some structure-activity relationship.

\section{ACKNOWLEDGEMENTS}

This investigation was subsidised by the FONDECYT (Chile, Grant $N^{\circ}$ 1060339), DICYT (Universidad de Antofagasta) and "Proyecto Anillo ACT-38".

\section{REFERENCES}

1. Schulz, V.; Phytomedicine 2003, 10, 74.

2. Mukherjee, P.; Kumar, V.; Mal, M.; Houghton, P.; Phytomedicine 2007, 14, 289.

3. Zahid, S.; Ata, A.; Samarasekera, R.; Z. Naturforsch. B 2007, 62, 280.

4. Dzubak, P.; Hajduch, M.; Vydra, D.; Hustova, A.; Kvasnika, M.; Biedermann, D.; Markova, L.; Urban, M.; Sarek, J.; Nat. Prod. Rep. 2006, 23, 394

5. Wächter, G. A.; Matooq, G.; Hoffmann, J. J.; Maiese, W. M.; Singh, M. P.; Montenegro, G.; Timmermann, B. N.; J. Nat. Prod. 1999, 62, 1319.

6. Araya, J. E.; Neira, I.; da Silva, S.; Mortara, R. A.; Manque, P.; Cordero, E.; Sagua, H.; Loyola, A.; Bórquez, J.; Morales, G.; González, J.; Mem. Inst. Oswaldo Cruz 2003, 98, 413.

7. Loyola, L. A.; Bórquez, J.; Morales, G.; San-Martín, A.; Darias, J.; Flores, N.; Giménez, A.; Phytochemistry 2004, 65, 1931.

8. Bohlmann, F.; Zdero, C.; Trenel, J.; Haenel, P.; Grenz, M.; Chem. Ber. 1971, 140, 1322.

9. Areche, C.; Rodriguez, J.; Razmilic, I.; Yañez, T.; Theoduloz, C; Schmeda-Hirschmann, G.; J. Pharm. Pharmacol. 2007, 59, 289.

10. Gutierrez, M.; Theoduloz, C.; Rodriguez, J.; Lolas, M.; SchmedaHirschmann, G.; J. Agric. Food Chem. 2005, 53, 7701.

11. Loyola, L. A.; Bórquez, J.; Morales, G.; San-Martín, A.; Phytochemistry 1996, 43, 165.

12. Loyola, L. A.; Bórquez, J.; Morales, G.; San-Martín, A.; Phytochemistry 1997, 44, 649 .

13. Emmons, G. T.; Wilson, W. K.; Schroepfer, G. J.; Magn. Reson. Chem. 1989, 27, 1012.

14. Kamisak, W.; Honda, C.; Suwa, K.; Isoi, K.; Magn. Reson. Chem. 1987, 25,683 .

15. Nyemba, A. M.; Mpondo, T. N.; Connolly, J. D.; Rycroft, D. S.; Phytochemistry 1990, 29, 994.

16. Dictionary of Natural Products on CD-ROM, Chapman and Hall/CRC: Boca Raton, 2007.

17. Wang, H. X.; Ng, T. B.; Life Sci. 1999, 65, 2663.

18. Rukmini, C.; Raghuram, T. C.; J. Am. Coll. Nutr. 1991, 10, 593.

19. Orhan, I.; Terzioglu, S.; Sener, B.; Planta Med. 2003, 69, 265.

20. Fujimoto, H.; Nakayama, M.; Nakayama, Y.; Yamazaki, M.; Chem. Pharm. Bull. 1994, 42, 694.

21. Li, C. H.; Chen, P. Y.; Chang, U. M.; Kan, L. S.; Fang, W. H.; Tsai, K. S.; Lin, S. B.; Life Sci. 2005, 77, 252. 